\title{
KORELASI ANTARA HORMON TESTOSTERON, LIBIDO, DAN KUALITAS SPERMA PADA KAMBING BLIGON, KEJOBONG, DAN PERANAKAN ETAWAH
}

\section{CORRELATION BETWEEN TESTOSTERONE, LIBIDO AND SPERM QUALITY OF BLIGON, KEJOBONG AND ETTAWA GRADE BUCKS}

\author{
Laili Rachmawati $^{1 *}$, Ismaya ${ }^{1}$, dan Pudji Astuti ${ }^{2}$ \\ ${ }^{1}$ Fakultas Peternakan, Universitas Gadjah Mada, Jl. Fauna No. 3, Bulaksumur, Yogyakarta, 55281 \\ ${ }^{2}$ Fakultas Kedokteran Hewan, Universitas Gadjah Mada, Jl. Fauna No. 2, Bulaksumur, Yogyakarta, 55281
}

\section{INTISARI}

Penelitian ini bertujuan untuk mengetahui hubungan antara kadar hormon testosteron, libido, dan kualitas sperma kambing Bligon, Kejobong, dan Peranakan Etawah (PE). Sampel terdiri dari 3 ekor kambing Bligon, 3 ekor kambing Kejobong, dan 3 ekor kambing PE jantan. Kadar testosteron diukur menggunakan metode enzyme-linked immunosorbent assay (ELISA). Tingkat libido diketahui dengan pengamatan waktu pertama mencumbu betina, menaiki betina, sampai ejakulasi. Penampungan sperma menggunakan metode vagina buatan. Data yang diperoleh kemudian ditentukan nilai korelasi antara kadar testosteron dengan libido dan kualitas sperma. Hasil menunjukkan testosteron pagi kambing Bligon berkorelasi terhadap waktu mencumbu betina $(\mathrm{R}=-0,79$ dan $\mathrm{Y}=20,91-6,52 \mathrm{X})$, menaiki betina $(\mathrm{R}=-0,80$ dan $\mathrm{Y}=20,28-7,16 \mathrm{X})$, ejakulasi $(\mathrm{R}=-0,81$ dan $\mathrm{Y}=14,03-7,56 \mathrm{X})$, volume sperma $(\mathrm{R}=0,65$ dan $\mathrm{Y}=-0,78+0,03 \mathrm{X})$, dan motilitas spermatozoa $(\mathrm{R}=0,70$ dan $\mathrm{Y}=-73,83+1,43 \mathrm{X})(\mathrm{P}<0,01)$. Testosteron pagi kambing Kejobong berkorelasi terhadap waktu mencumbu betina $(\mathrm{R}=-0,75$ dan $\mathrm{Y}=14,96-0,68 \mathrm{X})$, menaiki betina $(\mathrm{R}=-0,69$ dan $\mathrm{Y}=21,59-0,86 \mathrm{X})$, ejakulasi $(\mathrm{R}=-0,66$ dan $\mathrm{Y}=28,51-0,83 \mathrm{X})$, dan konsentrasi spermatozoa $(\mathrm{R}=0,59$ dan $\mathrm{Y}=430,73+12,75 \mathrm{X})(\mathrm{P}<0,01)$, sedangkan testosteron sore berkorelasi terhadap waktu mencumbu betina $(\mathrm{R}=-0,90$ dan $\mathrm{Y}=21,50-1,06 \mathrm{X})$, menaiki betina $(\mathrm{R}=-0,90$ dan $\mathrm{Y}=24,89-1,16 \mathrm{X})$, dan ejakulasi $(\mathrm{R}=-0,84$ dan $\mathrm{Y}=34,27-1,14 \mathrm{X})$ $(\mathrm{P}<0,01)$. Testosteron sore kambing $\mathrm{PE}$ berkorelasi terhadap waktu mencumbu betina $(\mathrm{R}=-0,72$ dan $\mathrm{Y}=12,83-7,31 \mathrm{X})$, menaiki betina $(\mathrm{R}=-0,72$ dan $\mathrm{Y}=9,11-7,67 \mathrm{X})$, ejakulasi $(\mathrm{R}=-0,69$ dan $\mathrm{Y}=2,02-8,25 \mathrm{X})$, viabilitas spermatozoa $(\mathrm{R}=0,77$ dan $\mathrm{Y}=-90,99+2,20 \mathrm{X})$ dan konsentrasi spermatozoa $(\mathrm{R}=0,72$ dan $\mathrm{Y}=-452,10+9,56 \mathrm{X})(\mathrm{P}<0,01)$. Disimpulkan bahwa terdapat korelasi antara kadar hormon testosteron dengan tingkat libido dan kualitas sperma, serta terdapat variasi korelasi diantara bangsa kambing.

(Kata kunci: Korelasi, Testosteron, Libido, Kualitas sperma, Kambing)

\section{ABSTRACT}

Aim of this study was to investigate the correlation value among testosterone concentrations, libido and sperm quality of Bligon, Kejobong and Ettawa Grade bucks. Samples used were 9 bucks (3 Bligon, 3 Kejobong and 3 PE). Testosterone was measured by enzyme-linked immunosorbent assay (ELISA) method. Libido observation were quantified at the first time to sniff, mount and finally ejaculation. Sperm was collected by using artificial vagina. Data of correlation between testosterones, libido and sperm quality was determined. Results showed that Bligon's testosterone in the morning was correlated with the first time to sniff $(R=-0.79$ and $Y=20.91-6.52 X)$, to mount $(R=-0.80$ and $Y=20.28-7.16 X)$, to ejaculation $(R=-0.81$ and $Y=14.03-7.56 X)$, sperm volume $(R=0.65$ and $Y=-0.78+0.03 X)$ and motility of spermatozoa $(R=0.70$ and $Y=-73.83+1.43 X)(P<0.01)$. Kejobong's testosterone in the morning was correlated with the first time to sniff $(R=-0.75$ and $Y=14.96-0.68 X)$, to mount $(R=-0.69$ and $Y=21.59-0.86 X)$, to ejaculate $(R=-0.66$ and $Y=28.51-0.83 X)$ and concentration of spermatozoa $(R=0.59$ and $Y=430.73+12.75 X)(P<0.01)$, whereas Kejobong's testosterone in the afternoon was correlated with the first time to sniff $(R=-0.90$ and $Y=21.50-1.06 X)$, to mount $(R=-0,90$ and $Y=24.89-1.16 X)$ and to ejaculate $(R=-0.84$ and $Y=34.27-1.14 X)(P<0.01)$. Testosterone in the afternoon of $P E$ was correlated with the first time to sniff $(R=-0.72$ and $Y=12.83-7.31 X)$, to mount $(R=-0.72$ and $Y=9.11-7.67 X)$ and to ejaculation $(R=-0.69$ and $Y=2.02-8.25 X)(P<0.01)$, spermatozoa viability $(R=0.77$ and $Y=-90.99+2.20 X)$ and spermatozoa concentration $(R=0.72$ and $Y=-452.10+9.56 X)(P<0.01)$. It could be concluded that testosterone level was correlated with libido and sperm quality, and there were variations of correlation between breed of bucks.

(Key words: Correlation, Testosterone, Libido, Sperm quality, Bucks)

\footnotetext{
* Korespondensi (corresponding author):

Telp. +62 8562943315

E-mail: laili.rachmawati@mail.ugm.ac.id
} 


\section{Pendahuluan}

Jenis kambing lokal yang banyak diternakkan di pulau Jawa antara lain kambing Bligon, Kejobong, dan Peranakan Etawah (PE). Menurut Budisatria et al. (2009), kambing Bligon, Kejobong, dan PE merupakan jenis kambing yang dapat beradaptasi terhadap kondisi dan habitat Indonesia, sehingga berpotensi untuk diternakkan lebih lanjut. Saat ini, potensi reproduksi pejantan kambing lokal tersebut belum banyak dilaporkan.

Potensi reproduksi pejantan ditentukan dari kemampuan untuk mengawini betina dan kemampuan untuk menghasilkan sperma (Toelihere, 2006). Pengamatan tingkah laku kawin sangat diperlukan untuk menentukan tingkat libido seekor pejantan (Rizal, 2005). Lebih lanjut dijelaskan oleh Muryanti (2005), tingkat libido serta proses spermatogenesis dikendalikan oleh hormon testosteron. Setiap bangsa kambing diduga memiliki nilai hubungan (korelasi) antara kadar hormon testosteron, tingkat libido, dan kualitas sperma yang berbeda-beda.

Berangkat dari hal tersebut maka perlu dilakukan penelitian lebih lanjut mengenai korelasi antara kadar hormon testosteron, libido, dan kualitas sperma beberapa bangsa kambing lokal di Indonesia. Penelitian ini bertujuan untuk mengetahui hubungan (korelasi) antara kadar hormon testosteron, libido, dan kualitas sperma pada kambing Bligon, Kejobong, dan PE, sehingga dengan penelitian ini diharapkan mampu memberikan informasi sebagai dasar penelitian selanjutnya dalam upaya menggali potensi reproduksi, meningkatkan produktivitas, menjaga kelestarian plasma nutfah, dan mendapatkan bibit unggul ternak-ternak lokal.

\section{Materi dan Metode}

\section{Lokasi dan waktu penelitian}

Penelitian dilaksanakan di Laboratorium Fisiologi dan Reproduksi Ternak Fakultas Peternakan, serta Laboratorium Fisiologi dan Patologi Klinik Fakultas Kedokteran Hewan Universitas Gadjah Mada, Yogyakarta. Data dikoleksi dari tanggal 2 Agustus sampai 23 November 2012. Pengambilan data dilakukan setiap pagi dengan 5 kali pengulangan, dan sore dengan 4 kali pengulangan untuk masing-masing bangsa kambing.

\section{Materi}

Ternak. Ternak yang digunakan sebanyak 9 ekor kambing jantan berumur \pm 18 bulan, yaitu tiga ekor kambing Bligon $(22,36 \pm 2,29 \mathrm{~kg})$, tiga ekor kambing Kejobong $(28,45 \pm 2,64 \mathrm{~kg})$, dan tiga ekor kambing PE $(38,57 \pm 5,82 \mathrm{~kg})$. Ternak dikandangkan secara individu. Pakan yang diberikan berupa jerami kacang tanah dan pollard dengan proporsi pemberian masing-masing sebesar $55 \%$ dan $45 \%$. Pemberian hijauan dan konsentrat secara berturutturut yaitu sebesar 1146,63 g/ekor/hari dan 315,27 g/ekor/hari untuk kambing Bligon, 1719,94 g/ekor/hari dan 472,86 g/ekor/hari untuk kambing Kejobong, serta 2006,60 g/ekor/hari dan 551,66 g/ekor/hari untuk kambing PE. Air minum diberikan secara bebas sepanjang hari.

Pengambilan darah. Materi yang digunakan untuk pengambilan sampel darah adalah tabung vacum blood collection kapasitas $3 \mathrm{ml}$ yang sudah dilengkapi EDTA (BD vacutainer ${ }^{\circledR}$, K2 EDTA (K2E) $5,4 \mathrm{mg}$ ), jarum (BD vacutainer $^{\circledR}$, PrecisionGlide $^{\mathrm{TM}}$, Multiple Sample needle 0,7x38 $\mathrm{mm}$ ), holder, alkohol 70\%, kapas, centrifuge (Hettich EBA20 Portable Centrifuge C2002, DJB Labcare Ltd, England), tabung plasma kapasitas 2 $\mathrm{ml}$, dan freezer (suhu $-20^{\circ} \mathrm{C}$ ).

Pengukuran kadar hormon testosteron. Hormon testosteron diukur menggunakan alat antara lain: Shaker (model VRN-200, Gemmy Industrial Corp, Taiwan), Immuno wash (model 1575, Cat. No. 170-7009, Bio-Rad, California, USA), Benchmark Microplate Reader (Cat. No. 170-6850, Bio-Rad, California, USA), dan seperangkat alat serta bahan DRG Testosterone ELISA Kit (DRG Testosterone ELISA EIA-1559, DRG Instruments GmbH, Germany).

Pengukuran libido. Materi yang dibutuhkan adalah kandang kawin, penghitung waktu, dan betina pemancing.

Penampungan dan pemeriksaan kualitas sperma. Alat yang digunakan adalah vagina buatan, tabung penampung sperma berskala, termometer batang, termos, haemocytometer, gelas objek, deglass, mikroskop, perangkat optilab, counter, pipet, dan benzen. Bahan yang digunakan yaitu vaselin, air suhu $\pm 42^{\circ} \mathrm{C}$, eosin dan larutan hayem.

\section{Metode}

Pengambilan data dilakukan setiap pagi (pukul 05.30 sampai 07.30) dan sore (pukul 15.00 sampai 16.00). Suhu selama penelitian berlangsung pada pagi hari berkisar antara $24^{\circ} \mathrm{C}$ sampai $27^{\circ} \mathrm{C}$, dan pada sore hari berkisar antara $31^{\circ} \mathrm{C}$ sampai $34^{\circ} \mathrm{C}$. Kelembaban yang terukur selama penelitian adalah $\pm 75 \%$.

Pengukuran kadar hormon testosteron. Darah dikoleksi dari bagian vena jugularis sebanyak $\pm 3 \mathrm{ml}$, kemudian diambil bagian plasma dan disimpan pada suhu $-20^{\circ} \mathrm{C}$ sampai uji hormon dilakukan. Kadar hormon testosteron diukur menggunakan metode enzyme-linked immunosorbent assay (ELISA) (DRG, 2009). 
Pengukuran libido. Pengukuran libido menggunakan betina estrus. Libido diukur dengan mencatat waktu pertama pejantan mencumbu betina, waktu pertama kali menaiki betina, dan waktu terjadinya ejakulasi (Hastono dan Arifin, 2006). Betina diletakkan pada kandang yang terpisah, ketika pejantan dimasukkan ke dalam kandang betina lalu dicatat waktu pertama pejantan mulai mendekati betina yang ditunjukkan dengan reaksi mengendus-ngendus betina (dihitung sebagai waktu pertama mencumbu), selanjutnya ketika pejantan berusaha menaiki betina untuk pertama kali maka dihitung sebagai waktu pertama menaiki, dan yang terakhir ketika pejantan berhasil melakukan aksi perkawinan dan terjadi ejakulasi pertama maka dihitung sebagai waktu pertama terjadi ejakulasi.

Penampungan dan pemeriksaan kualitas sperma. Penampungan sperma menggunakan metode vagina buatan (Ismaya et al., 2008). Sperma yang berhasil ditampung segera dilakukan pemeriksaan volume sperma, motilitas, viabilitas, dan konsentrasi spermatozoa.

\section{Analisis data}

Data dianalisis dengan program SPSS versi 17.0 for windows. Analisis yang digunakan adalah analisis korelasi yang dilanjutkan dengan analisis regresi (Astuti, 2007).

\section{Hasil dan Pembahasan}

Hasil yang diperoleh dari pengukuran terhadap kadar hormon testosteron, tingkat libido, dan kualitas sperma pada kambing Bligon tersaji pada Tabel 1.

Pengukuran yang dilakukan setiap pagi dan sore terhadap kadar hormon testosteron, libido, dan kualitas sperma pada bangsa kambing Kejobong diperoleh data seperti tersaji pada Tabel 2.

Pengukuran selanjutnya dilakukan pada bangsa kambing PE. Berdasarkan hasil pengukuran terhadap bangsa kambing PE yang meliputi pengukuran kadar hormon testosteron pagi, kadar hormon testosteron sore, tingkat libido pagi, tingkat libido sore, kualitas sperma pagi, dan kualitas sperma sore maka diperoleh data yang dapat dilihat pada Tabel 3.

\section{Korelasi antara kadar hormon testosteron dengan tingkat libido}

Berdasarkan hasil yang diperoleh pada Tabel 1, 2, dan 3, selanjutnya ditentukan nilai korelasi antara kadar hormon testosteron, tingkat libido, dan kualitas sperma dari masing-masing bangsa. Besarnya nilai korelasi ditentukan dari nilai regresi (R) yang diperoleh dari hasil analisis. Hubungan (korelasi) antara kadar hormon testosteron pagi terhadap tingkat libido pada kambing Bligon, Kejobong, dan PE tersaji pada Tabel 4. Korelasi antara kadar hormon testosteron sore terhadap tingkat libido pada kambing Bligon, Kejobong, dan PE tersaji pada Tabel 5.

Berdasarkan hasil analisis yang tersaji pada Tabel 4 diketahui bahwa kadar hormon testosteron pagi kambing Bligon memiliki korelasi sangat kuat $(\mathrm{P}<0,01)$ terhadap waktu mencumbu betina dengan koefisien regresi $(\mathrm{R})$ sebesar $-0,79$, waktu menaiki betina $(\mathrm{R}=-0,80)$, dan waktu terjadi ejakulasi $(\mathrm{R}=-0,81)$ dengan persamaan regresi berturut-turut sebesar $\mathrm{Y}=20,91-6,52 \mathrm{X} ; \mathrm{Y}=20,28-7,16 \mathrm{X}$; dan $\mathrm{Y}=14,03-7,56 \mathrm{X}$. Kambing Kejobong juga menunjukkan korelasi yang sangat kuat $(\mathrm{P}<0,01)$ antara kadar hormon testosteron pagi terhadap waktu mencumbu betina $(R=-0,75)$, waktu menaiki betina $(\mathrm{R}=-0,69)$, dan waktu terjadi ejakulasi $(\mathrm{R}=-0,66)$ dengan persamaan regresi berturut-turut yaitu $\mathrm{Y}=14,96-0,68 \mathrm{X} ; \mathrm{Y}=21,59-0,86 \mathrm{X}$; dan $\mathrm{Y}=$ 28,51-0,83X. Kambing PE menunjukkan hasil korelasi yang lemah antara kadar testosteron pagi dengan tingkat libido.

Kambing Bligon dan Kejobong memiliki kadar testosteron pagi yang berkorelasi sangat nyata $(\mathrm{P}<0,01)$ terhadap tingkat libido. Koefisien regresi (R) yang mendekati nilai -1 menunjukkan adanya korelasi yang kuat dan terjadi hubungan linier yang mendekati sempurna antara dua variabel yang terukur dengan hubungan yang berlawanan atau negatif, atau semakin tinggi kadar hormon testosteron maka diikuti semakin rendah waktu untuk mencumbu betina, menaiki betina, dan terjadi ejakulasi. Hal tersebut sesuai pendapat Astuti (2007) yang menyatakan nilai $\mathrm{R}$ terletak dari -1 sampai $+1 \quad(-1 \leq \mathrm{R} \leq+1)$, korelasi sebesar +1 menyatakan bahwa korelasinya adalah positif dan sempurna, sedangkan korelasi sebesar -1 menyatakan bahwa korelasinya adalah negatif dan sempurna, untuk nilai korelasi sebesar 0 (nol) menunjukkan tidak ada hubungan antara dua variabel. Jika nilai $\mathrm{R}$ mendekati 0 maka hubungan yang terjadi adalah sangat lemah (Matondang, 2012).

Hasil yang tersaji pada Tabel 5 menunjukkan bahwa kambing Kejobong memiliki korelasi yang sangat nyata $(\mathrm{P}<0,01)$ antara kadar testosteron sore terhadap waktu mencumbu, menaiki, dan ejakulasi. Tabel 5 juga memperlihatkan kambing PE memiliki korelasi yang sangat nyata $(\mathrm{P}<0,01)$ antara kadar testosteron sore terhadap waktu mencumbu dan menaiki, sedangkan korelasi antara kadar testosteron sore dengan waktu terjadi ejakulasi kambing $\mathrm{PE}$ menunjukkan korelasi nyata $(\mathrm{P}<0,05)$. Kadar testosteron sore kambing Bligon berkorelasi terhadap tingkat libido, tapi menunjukkan korelasi yang lemah (Tabel 5). 
Tabel 1. Kadar hormon tersosteron, tingkat libido, dan kualitas sperma pada kambing Bligon (testosterone level, libido and sperm quality of Bligon bucks)

\begin{tabular}{lrrrrr}
\hline \hline & \multicolumn{5}{c}{ Rata-rata pengukuran (measurement average) } \\
\cline { 2 - 6 } & \multicolumn{1}{c}{1} & \multicolumn{1}{c}{2} & 3 & \multicolumn{1}{c}{4} & 5 \\
\hline Pagi (morning) & & & & & \\
Testosteron (ng/ml) (testosterone (ng/ml)) & 9,75 & 10,52 & 10,64 & 9,19 & 6,03 \\
Mencumbu (detik) (sniff (second)) & 36,69 & 39,64 & 42,10 & 39,33 & 38,24 \\
Menaiki (detik) (mount (second)) & 42,91 & 44,43 & 49,40 & 47,08 & 45,33 \\
Ejakulasi (detik) (ejaculation (second)) & 55,67 & 54,21 & 58,81 & 57,25 & 52,58 \\
Volume (ml) (volume (ml)) & 0,63 & 0,51 & 0,53 & 0,46 & 0,56 \\
Motilitas (\%) (motility (\%)) & 65,00 & 61,67 & 58,33 & 58,33 & 60,00 \\
Viabilitas (\%) (viability (\%)) & 84,50 & 81,58 & 69,52 & 57,16 & 68,69 \\
Konsentrasi (\%) (concentration (\%)) & 432,33 & 439,00 & 433,00 & 546,66 & 461,66 \\
Sore (afternoon) & & & & & \\
Testosteron (ng/ml) (testosterone (ng/ml)) & 11,72 & 12,79 & 6,68 & 6,12 & \\
Mencumbu (detik) (sniff (second)) & 34,62 & 36,64 & 40,56 & 34,09 & \\
Menaiki (detik) (mount (second)) & 41,74 & 43,83 & 46,46 & 37,76 & \\
Ejakulasi (detik) (ejaculation (second)) & 50,43 & 54,33 & 59,22 & 46,85 & \\
Volume (ml) (volume (ml)) & 0,61 & 0,53 & 0,54 & 0,47 & \\
Motilitas (\%) (motility (\%)) & 64,87 & 61,65 & 58,32 & 58,35 & \\
Viabilitas (\%) (viability (\%)) & 83,98 & 81,58 & 69,51 & 57,17 & \\
Konsentrasi (\%) (concentration (\%)) & 432,38 & 429,00 & 387,00 & 389,95 & \\
\hline
\end{tabular}

Tabel 2. Kadar hormon tersosteron, tingkat libido, dan kualitas sperma pada kambing Kejobong (testosterone level, libido and sperm quality of Kejobong bucks)

\begin{tabular}{|c|c|c|c|c|c|}
\hline & \multicolumn{5}{|c|}{ Rata-rata pengukuran (measurement average) } \\
\hline & 1 & 2 & 3 & 4 & 5 \\
\hline \multicolumn{6}{|l|}{ Pagi (morning) } \\
\hline Testosteron $(\mathrm{ng} / \mathrm{ml})($ testosterone $(\mathrm{ng} / \mathrm{ml}))$ & 13,36 & 14,98 & 11,60 & 9,81 & 10,24 \\
\hline Mencumbu (detik) (sniff (second)) & 6,62 & 7,57 & 7,01 & 5,86 & 6,78 \\
\hline Menaiki (detik) (mount (second)) & 10,79 & 11,25 & 10,72 & 10,80 & 12,79 \\
\hline Ejakulasi (detik) (ejaculation (second)) & 18,09 & 17,48 & 18,21 & 18,39 & 20,06 \\
\hline Volume $(\mathrm{ml})($ volume $(\mathrm{ml}))$ & 0,56 & 0,61 & 0,53 & 0,73 & 0,63 \\
\hline Motilitas (\%) (motility (\%)) & 78,33 & 80,00 & 76,66 & 70,00 & 73,33 \\
\hline Viabilitas (\%) (viability (\%)) & 95,00 & 91,50 & 71,98 & 76,53 & 63,66 \\
\hline Konsentrasi (\%) (concentration (\%)) & 731,33 & 626,33 & 472,66 & 496,66 & 592,33 \\
\hline \multicolumn{6}{|l|}{ Sore (afternoon) } \\
\hline Testosteron $(\mathrm{ng} / \mathrm{ml})($ testosterone $(\mathrm{ng} / \mathrm{ml}))$ & 11,04 & 13,20 & 12,04 & 11,55 & \\
\hline Mencumbu (detik) (sniff (second)) & 8,69 & 9,07 & 8,80 & 8,70 & \\
\hline Menaiki (detik) (mount (second)) & 10,20 & 10,68 & 11,06 & 11,70 & \\
\hline Ejakulasi (detik) (ejaculation (second)) & 19,53 & 19,26 & 21,18 & 22,42 & \\
\hline Volume $(\mathrm{ml})($ volume $(\mathrm{ml}))$ & 0,52 & 0,81 & 0,59 & 0,53 & \\
\hline Motilitas (\%) (motility (\%)) & 78,43 & 86,60 & 70,69 & 70,00 & \\
\hline Viabilitas (\%) (viability (\%)) & 71,98 & 90,70 & 98,00 & 76,51 & \\
\hline Konsentrasi $(\%)$ (concentration $(\%))$ & 528,84 & 740,00 & 697,62 & 477,89 & \\
\hline
\end{tabular}

Kambing Kejobong memiliki nilai korelasi antara testosteron sore terhadap waktu mencumbu betina dengan $\mathrm{R}=-0,90$ dan $\mathrm{Y}=21,50-1,06 \mathrm{X}$, terhadap waktu menaiki betina dengan $\mathrm{R}=-90$ dan $\mathrm{Y}=24,89-1,16 \mathrm{X}$, serta terhadap waktu terjadi ejakulasi dengan $\mathrm{R}=-0,84$ dan $\mathrm{Y}=34,27-1,14 \mathrm{X}$.
Korelasi antara kadar testosteron sore dan tingkat libido kambing PE memperlihatkan koefisien dan persamaan regresi berturut-turut untuk waktu mencumbu betina yaitu $\mathrm{R}=-0,72$ dan $\mathrm{Y}=12,83$ 7,31X, waktu untuk menaiki betina $\mathrm{R}=-0,72$ dan 
Tabel 3. Kadar hormon tersosteron, tingkat libido, dan kualitas sperma pada kambing Peranakan Etawah (testosterone level, libido and sperm quality of Ettawa Grade bucks)

\begin{tabular}{lrrrrr}
\hline \hline & \multicolumn{5}{c}{ Rata-rata pengukuran (measurement average) } \\
\cline { 2 - 6 } & \multicolumn{1}{c}{1} & \multicolumn{1}{c}{2} & \multicolumn{1}{c}{3} & \multicolumn{1}{c}{4} & 5 \\
\hline Pagi (morning) & & & & & \\
Testosteron (ng/ml) (testosterone (ng/ml)) & 5,49 & 10,28 & 9,44 & 4,94 & 3,93 \\
Mencumbu (detik) (sniff (second)) & 38,47 & 43,12 & 50,06 & 42,46 & 41,39 \\
Menaiki (detik) (mount (second)) & 45,67 & 53,52 & 60,41 & 53,42 & 58,33 \\
Ejakulasi (detik) (ejaculation (second)) & 59,04 & 62,17 & 70,19 & 68,01 & 76,17 \\
Volume (ml) (volume (ml)) & 1,08 & 0,81 & 0,80 & 1,01 & 6,66 \\
Motilitas (\%) (motility (\%)) & 66,66 & 60,00 & 63,33 & 65,66 & 60,00 \\
Viabilitas (\%) (viability (\%)) & 81,44 & 74,19 & 64,64 & 76,47 & 60,54 \\
Konsentrasi (\%) (concentration (\%)) & 383,00 & 376,33 & 361,00 & 397,00 & 360,66 \\
Sore (afternoon) & & & & & \\
Testosteron (ng/ml) (testosterone (ng/ml)) & 6,02 & 9,72 & 10,62 & 4,06 & \\
Mencumbu (detik) (sniff (second)) & 42,88 & 46,68 & 42,90 & 38,89 & \\
Menaiki (detik) (mount (second)) & 49,76 & 53,16 & 49,09 & 45,00 & \\
Ejakulasi (detik) (ejaculation (second)) & 61,85 & 61,42 & 61,09 & 58,76 & \\
Volume (ml) (volume (ml)) & 1,07 & 0,91 & 0,77 & 1,00 & \\
Motilitas (\%) (motility (\%)) & 67,66 & 61,03 & 67,33 & 62,67 & \\
Viabilitas (\%) (viability (\%)) & 84,50 & 84,19 & 94,74 & 66,30 & \\
Konsentrasi (\%) (concentration (\%)) & 381,10 & 403,56 & 361,20 & 387,17 & \\
\hline
\end{tabular}

Tabel 4. Korelasi antara kadar hormon testosteron pagi dengan tingkat libido (correlation between testosterone level in the morning with libido)

\begin{tabular}{lccc}
\hline \hline \multirow{2}{*}{$\begin{array}{c}\text { Testosteron pagi (testosterone in the } \\
\text { morning) }\end{array}$} & \multicolumn{2}{c}{ Libido pagi (detik) (libido in the morning (second)) } \\
\cline { 2 - 4 } & Mencumbu (sniff) & Menaiki (mount) & Ejakulasi (ejaculation) \\
\hline Bligon & $-0,79^{* *}$ & $-0,80^{* *}$ & $-0,81^{* *}$ \\
Kejobong & $-0,75^{* *}$ & $-0,69^{* *}$ & $-0,66^{* *}$ \\
Peranakan Etawah (Ettawa Grade) & $-0,49$ & $-0,46$ & $-0,38$ \\
\hline
\end{tabular}

** menunjukkan korelasi sangat nyata $(\mathrm{P}<0,01)$ (showed highly significant correlation $(P<0.01))$.

Tabel 5. Korelasi antara kadar hormon testosteron sore dengan tingkat libido (correlation between testosterone level in the afternoon with libido)

\begin{tabular}{lccc}
\hline \multirow{2}{*}{$\begin{array}{c}\text { Testosteron sore (testosterone in the } \\
\text { afternoon) }\end{array}$} & \multicolumn{2}{c}{ Libido sore (detik) (libido in the afternoon (second) $)$} \\
\cline { 2 - 4 } & Mencumbu (sniff) & Menaiki (mount) & Ejakulasi (ejaculation) \\
\hline Bligon & $-0,47$ & $-0,49$ & $-0,47$ \\
Kejobong & $-0,90^{* *}$ & $-0,90^{* *}$ & $-0,84^{* *}$ \\
Peranakan Etawah (Ettawa Grade) & $-0,72^{* *}$ & $-0,72^{* *}$ & $-0,69^{*}$ \\
\hline
\end{tabular}

* menunjukkan korelasi nyata $(\mathrm{P}<0,05)$ (showed significant correlation $(P<0.05))$.

** menunjukkan korelasi sangat nyata $(\mathrm{P}<0,01)$ (showed highly significant correlation $(P<0.01))$.

$\mathrm{Y}=9,11-7,67 \mathrm{X}$, serta waktu terjadi ejakulasi $\mathrm{R}=$ $-0,69$ dan $Y=2,02-8,25 X$.

Korelasi negatif antara kadar testosteron sore terhadap tingkat libido menunjukkan adanya hubungan linier dengan hubungan yang berlawanan (negatif). Kambing Kejobong dan PE menunjukkan hubungan berlawanan yang sangat kuat dan kuat $(\mathrm{P}<0,01$ dan $\mathrm{P}<0,05)$, karena memiliki nilai $\mathrm{R}$ yang mendekati -1. Kambing Bligon menunjukkan hubungan berlawanan yang lemah karena nilai $\mathrm{R}$ mendekati 0 .

Persamaan regresi yang diperoleh menunjukkan besarnya perubahan nilai $\mathrm{Y}$ yang dipengaruhi oleh $\mathrm{X}$, dalam hal ini $\mathrm{X}$ adalah kadar hormon testosteron dan $\mathrm{Y}$ adalah tingkat libido (waktu mencumbu, menaiki, dan ejakulasi). Nilai Y 
semakin rendah apabila nilai $\mathrm{X}$ meningkat, hal tersebut berarti kadar hormon testosteron yang meningkat diikuti semakin cepat waktu yang dibutuhkan pejantan untuk mencumbu, menaiki, dan mengawini betina, seperti pada Tabel 1, 2, dan 3.

Penelitian ini menunjukkan adanya variasi korelasi antara kadar testosteron terhadap tingkat libido yaitu sangat kuat, kuat, maupun lemah. Hal tersebut disebabkan karena adanya variasi bangsa yang digunakan. Menurut Kafi et al. (2004), ditemukan adanya respon yang berbeda diantara bangsa pada stimulus testosteron dalam mempengaruhi aktivitas seksual khususnya pejantan.

Korelasi sangat kuat maupun kuat antara kadar hormon testosteron dengan tingkat libido yang terjadi dalam penelitian ini sesuai seperti penelitian Barkawi et al. (2006) yang mendapatkan peningkatan kadar hormon testosteron selama musim panas diikuti semakin cepat waktu untuk terjadi ejakulasi. Al-Sobayil et al. (2008) juga mendapatkan adanya korelasi positif antara kadar hormon testosteron terhadap tingkat libido pada kambing yang diberi pakan dengan kandungan protein yang berbeda.

Testosteron adalah hormon yang terlibat dengan sexual desire (libido) yang memberikan stimulus seksual untuk mendorong aktivitas seksual khususnya pada hewan jantan (Rachmadi, 2008). Ketersediaan testosteron yang cukup akan menyebabkan peningkatan akumulasi testosteron, akibatnya daerah yang mengaktifkan metabolisme otak dan mengatur libido menjadi aktif (Indrayanto,
2011). Bearden et al. (2004) menambahkan bahwa pejantan yang telah mencapai umur pubertas atau berada pada fase perkembangan seksual menunjukkan kadar hormon testosteron dalam plasma darah yang tinggi.

\section{Korelasi antara kadar hormon testosteron dengan kualitas sperma}

Tabel 6 menyajikan korelasi antara kadar hormon testosteron pagi terhadap kualitas sperma pada kambing Bligon, Kejobong, dan PE selama bulan Agustus sampai November 2012.

Data penelitian selain diambil pada pagi hari juga diambil pada sore hari. Korelasi antara kadar hormon testosteron sore terhadap kualitas sperma pada kambing Bligon, Kejobong, dan PE tersaji pada Tabel 7.

Hasil penelitian yang tercantum pada Tabel 6 adalah kadar hormon testosteron pagi kambing Bligon berkorelasi sangat kuat $(\mathrm{P}<0,01)$ terhadap volume sperma dan motilitas spermatozoa. Kambing Bligon memiliki koefisien dan persamaan regresi antara kadar testosteron pagi dengan volume sperma berturut-turut sebesar $\mathrm{R}=0,65$ dan $\mathrm{Y}=-0,78+0,03 \mathrm{X}$, serta koefisien dan persamaan regresi antara kadar testosteron pagi dengan motilitas spermatozoa berturut-turut sebesar $\mathrm{R}=0,70$ dan $\mathrm{Y}=-73,83+1,43 \mathrm{X}$. Tabel 3 juga memperlihatkan korelasi kuat $(\mathrm{P}<0,05)$ antara kadar testosteron pagi kambing Kejobong dengan konsentrasi sperma dengan $\mathrm{R}=0,59$ dan $\mathrm{Y}=430,73+12,75 \mathrm{X}$.

Tabel 6. Korelasi antara kadar hormon testosteron pagi dengan kualitas sperma (correlation between testosterone level in the morning and sperm quality)

\begin{tabular}{lcccc}
\hline \hline \multirow{2}{*}{$\begin{array}{c}\text { Testosteron pagi (testosterone in the } \\
\text { morning) }\end{array}$} & \multicolumn{4}{c}{ Kualitas sperma (sperm quality) } \\
\cline { 2 - 5 } & $\begin{array}{c}\text { Volume } \\
\text { (volume) }\end{array}$ & $\begin{array}{c}\text { Motilitas } \\
\text { (motility) }\end{array}$ & $\begin{array}{c}\text { Viabilitas } \\
\text { (viability) }\end{array}$ & $\begin{array}{c}\text { Konsentrasi } \\
\text { (concentration) }\end{array}$ \\
\hline Bligon & $0,65^{* *}$ & $0,70^{* *}$ & 0,24 & 0,11 \\
Kejobong & 0,23 & 0,26 & 0,28 & $0,59^{*}$ \\
Peranakan Etawah (Ettawa Grade) & 0,31 & 0,28 & 0,38 & 0,37 \\
\hline
\end{tabular}

* menunjukkan korelasi nyata $(\mathrm{P}<0,05)$ (showed significant correlation $(P \leq 0.05))$.

** menunjukkan korelasi sangat nyata $(\mathrm{P}<0,01)$ (showed highly significant correlation $(P<0.01))$.

Tabel 7. Korelasi antara kadar hormon testosteron sore dengan kualitas sperma (correlation between testosterone level in the afternoon and sperm quality)

\begin{tabular}{lcccc}
\hline \hline \multirow{2}{*}{$\begin{array}{c}\text { Testosteron sore (testosterone in the } \\
\text { afternoon) }\end{array}$} & \multicolumn{4}{c}{ Kualitas sperma (sperm quality) } \\
\cline { 2 - 5 } & $\begin{array}{c}\text { Volume } \\
\text { (volume) }\end{array}$ & $\begin{array}{c}\text { Motilitas } \\
\text { (motility) }\end{array}$ & $\begin{array}{c}\text { Viabilitas } \\
\text { (viability) }\end{array}$ & $\begin{array}{c}\text { Konsentrasi } \\
\text { (concentration) }\end{array}$ \\
\hline Bligon & 0,54 & 0,33 & 0,50 & 0,18 \\
Kejobong & 0,09 & 0,30 & 0,10 & 0,23 \\
Peranakan Etawah (Ettawa Grade) & 0,55 & 0,57 & $0,77^{* *}$ & $0,72^{* *}$ \\
\hline
\end{tabular}

** menunjukkan korelasi sangat nyata $(\mathrm{P}<0,01)$ (showed highly significant correlation $(P<0.01))$. 
Korelasi positif yang sangat kuat dan kuat $(\mathrm{P}<0,01$ dan $\mathrm{P}<0,05)$ antara kadar testosteron pagi terhadap volume dan motilitas sperma pada kambing Bligon, serta antara kadar testosteron pagi terhadap konsentrasi sperma pada kambing Kejobong karena nilai regresi $(\mathrm{R})$ mendekati +1 . Tabel 6 juga memperlihatkan adanya korelasi lemah antara kadar testosteron pagi terhadap kualitas sperma kambing PE karena R mendekati 0. Korelasi positif $(+)$ antara kadar hormon testosteron pagi dengan kualitas sperma menunjukkan bahwa terdapat hubungan dengan arah yang sama. Hal tersebut berarti semakin tinggi kadar hormon testosteron pagi maka diikuti dengan peningkatan kualitas sperma, ini sesuai dengan temuan Alkass dan Ahmed (2011) pada bangsa kambing Black dan Meriz.

Tabel 7 menunjukkan bahwa kadar hormon testosteron sore kambing PE berkorelasi sangat nyata $(\mathrm{P}<0,01)$ terhadap viabilitas spermatozoa dengan $\mathrm{R}=0,77$ dan $\mathrm{Y}=-90,99+2,20 \mathrm{X}$, serta terhadap konsentrasi spermatozoa dengan $\mathrm{R}=0,72$ dan $\mathrm{Y}=-452,10+9,56 \mathrm{X}$. Kadar testosteron sore dengan kualitas sperma pada kambing Bligon dan Kejobong seperti tersaji pada Tabel 7 menunjukkan adanya korelasi yang lemah.

Korelasi positif $(+\mathrm{R})$ antara kadar testosteron sore terhadap kualitas sperma menunjukkan adanya hubungan linier dengan hubungan yang sama (searah). Nilai $\mathrm{R}$ terletak dari -1 sampai +1 ($1 \leq \mathrm{R} \leq+1$ ), korelasi sebesar +1 menyatakan bahwa korelasinya adalah positif dan sempurna, sedangkan korelasi sebesar -1 menyatakan bahwa korelasinya adalah negatif dan sempurna, untuk nilai korelasi sebesar 0 (nol) menunjukkan tidak ada hubungan antara dua variabel (Astuti, 2007). Lebih lanjut dijelaskan oleh Matondang (2012), jika nilai R mendekati 0 maka hubungan yang terjadi adalah sangat lemah.

Penelitian ini menunjukkan adanya variasi korelasi antara kadar testosteron terhadap kualitas sperma yaitu sangat kuat, kuat, maupun lemah. Hal tersebut disebabkan karena adanya variasi bangsa yang digunakan. Menurut Kafi et al. (2004), ditemukan adanya respon yang berbeda diantara bangsa pada stimulus testosteron dalam mempengaruhi aktivitas seksual khususnya pejantan. AlOmari (2012) mendapatkan sperma yang diejakulasikan kambing Damaskus, Mointain Black, dan Persilangan antara Damaskus dan Mointain Black ternyata berhubungan dengan kadar hormon testosteron, yaitu setiap peningkatan kadar hormon testosteron maka diikuti dengan peningkatan kualitas sperma.
Persamaan regresi yang diperoleh menunjukkan besarnya perubahan nilai $\mathrm{Y}$ yang dipengaruhi oleh $\mathrm{X}$, dalam hal ini $\mathrm{X}$ adalah kadar hormon testosteron dan $\mathrm{Y}$ adalah kualitas sperma. Nilai $Y$ semakin tinggi apabila nilai $X$ meningkat, hal tersebut berarti kadar hormon testosteron yang meningkat diikuti semakin tinggi kualitas sperma yang diperoleh (volume, motilitas, viabilitas, dan konsentrasi).

Korelasi positif $(+)$ yang terjadi antara kadar hormon testosteron dengan kualitas sperma disebabkan karena hormon testosteron berperan penting bagi suatu tahap atau lebih dalam pembelahan sel-sel germinal untuk membentuk spermatozoa, terutama pembelahan meiosis untuk membentuk spermatosit sekunder (Guyton dan Hall, 1997). Muryanti (2005) menyatakan bahwa luteinizing hormone ( $\mathrm{LH})$ merangsang sel-sel leydig dalam jaringan interstitial testis untuk meningkatkan produksi testosteron. Lebih lanjut dijelaskan, follicle stimulating hormon (FSH) mempengaruhi sel-sel sertoli untuk menghasilkan androgen binding protein (ABP) yang dilepas ke dalam cairan testis untuk mengikat testosteron dan kemudian mempengaruhi proses spermatogenesis. Arthur (2001) menambahkan, kelangsungan hidup spermazoa dikontrol oleh keberadaan testosteron.

Hubungan antara kadar testosteron, tingkat libido, dan kualitas sperma yang ditunjukkan dalam penelitian ini sesuai dengan pendapat Rachmadi (2008), yaitu hormon testosteron yang berasal dari testis berperan dalam memacu pertumbuhan dan menjaga kelangsungan fungsi kelenjar-kelenjar kelamin pelengkap untuk menghasilkan plasma sperma pada saat ejakulasi, memacu keinginan pejantan untuk kawin (libido). Lebih lanjut dijelaskan, hormon testosteron berperan juga dalam kesanggupan pejantan untuk ereksi, dan ejakulasi. Mekanisme hormon testosteron dalam mencapai target sel dan selanjutnya menjalankan perannya dalam mempengaruhi aktivitas seksual pejantan adalah melalui difusi pasif (Brinkmann, 2009).

\section{Kesimpulan}

Berdasarkan penelitian ini disimpulkan bahwa terdapat korelasi antara kadar hormon testosteron terhadap tingkat libido dan kualitas sperma, yaitu semakin tinggi kadar hormon testosteron maka diikuti semakin tinggi tingkat libido dan semakin baik kualitas sperma. Terdapat variasi korelasi antara kadar hormon testosteron terhadap tingkat libido dan kualitas sperma dari kambing Bligon, Kejobong, dan PE. 


\section{Daftar Pustaka}

Alkass, J. E. and K. A. Ahmed. 2011. A comparative study on some semen characteristics and testosterone level of Black Goat and Meriz bucks. Agric. Vet. Sci. 14: 1-8.

Al-Omari, H. Y. 2012. Study of testosterone consentrations during breeding season of two breeds of goat bucks and their crossbred under exogenous $\mathrm{GnRH}$ treatments. Asian Anim. Vet. Adv. 7: 693-701.

Al-Sobayil, K. A., M. M. Zeitoun, M. H. Khalil and A. M. Abdel-Salam. 2008. Effect of oral administration of a functional synbiotic syrup on libido, semen characteristics, serum testosterone and liver and kidney function of goat's bucks. Asian J. Biol. Sci. 1: 11-18.

Arthur, G. H. 2001. Veterinary Reproduction and Obstetries, $8^{\text {th }}$ ed. Saunders. London.

Astuti, M. 2007. Pengantar Ilmu Statistik Untuk Peternakan dan Kesehatan Hewan. Binasti Publisher. Bogor.

Barkawi, A. H., E. H. Elsayed, G. Ashour and E. Shehata. 2006. Seasonal changes in semen characteristics, hormonal profiles and testicular activity in Zaraibi goats. Small Rumin. Res. 66: 209-213.

Bearden, H. J., J. W. Fuquay and S. T. Willard. 2004. Applied Animal Reproduction, $6^{\text {th }}$ ed. Pearson Prentice Hall. New Jersey.

Brinkmann, A. O. 2009. Androgen Physiology: Receptor and Metabolic Disorders. Department of Reproduction and Development, University Medical Center Rotterdam.

Budisatria, I. G. S., D. T. Widayati, B. Suhartanto, Kustantinah, H. Mulyadi and K. A. Santosa. 2009. Germ Plasm of Goats in Indonesia. UGM Press. Yogyakarta.

DRG. 2009. User's Manual Testosterone ELISA, EIA-1559. DRG Instruments $\mathrm{GmbH}$, Division of DRG International, Inc. New York.
Guyton, A. C. and J. E. Hall. 1997. Medical Physiology, $9^{\text {th }}$ ed. Saunders Company. Philadelphia.

Hastono dan J. Arifin. 2006. Hubungan bobot badan dengan lingkar skrotum, jumlah naik, dan jumlah ejakulasi domba Garut. Seminar Nasional Teknologi Peternakan dan Veteriner. Pusat Penelitian dan Pengembangan Peternakan, Bogor.

Indrayanto, Y. 2011. Andropause. Tesis. Fakultas Kedokteran, Universitas Sebelas Maret. Surakarta.

Ismaya, Kustono, S. Bintara, dan D. T. Widayati. 2008. Bahan Ajar Teknologi Reproduksi Ternak. Fakultas Peternakan, Universitas Gadjah Mada. Yogyakarta.

Kafi, M., M. Safdarian and M. Hashemi. 2004. Seasonal variation in semen characteristics, scrotal circumference and libido of Persian Karakul rams. Small Rumin. Res. 53: 133139.

Matondang, Z. 2012. Uji Korelasi dan Regresi. PT. Grasindo. Jakarta.

Muryanti, Y. 2005. Kadar testosteron serum darah dan kualitas spermatozoa mencit (Mus musculus L.) setelah diberi ekstrak biji saga (Abrus precatorius L.). Skripsi. Fakultas Kedokteran Hewan, Universitas Gadjah Mada. Yogyakarta.

Rachmadi, A. 2008. Kadar gula darah dan kadar hormon testosteron pada pria penderita diabetes melitus. Tesis. Fakultas Kedokteran, Universitas Diponegoro. Semarang.

Rizal, M. 2005. Fertilitas spermatozoa ejakulat dan epididimis domba Garut hasil kriopreservasi menggunakan modifikasi pengencer tris dengan berbagai krioprotektan dan antioksidan. Tesis. Fakultas Kedokteran Hewan, Institut Pertanian Bogor. Bogor.

Toelihere, M. R. 2006. Pokok-pokok Pikiran Seorang Begawan Reproduksi. Institut Pertanian Bogor Press. Bogor. 